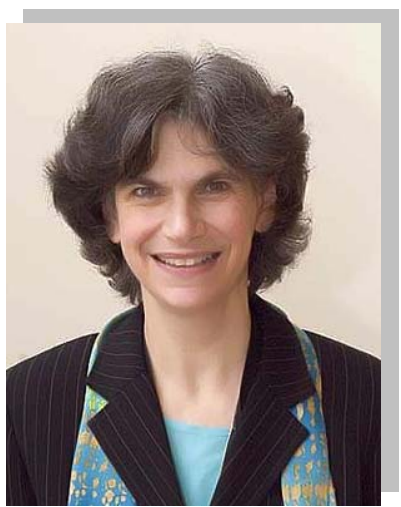

\section{Librarians in Disneyland}

By Jacqueline Snider

Book Review Editor \& Author Liaison

Water infiltrated the Midwest this summer. An unusually snowy and icy winter and a rainy spring produced flooding in Cedar Falls and Waterloo, then Cedar Rapids, and finally reached Iowa City in June. The University of Iowa was hit hard as Hancher Auditorium, the Art Museum, Music Building, Main Library, and many other buildings were in the "line of water." Thousands left their homes. Cedar Rapids Public Library is a total ruin as are many municipal buildings and historic houses downtown.

I am not relating these sad facts to elicit sympathy, although the communities affected could certainly use it, but because I found references to the floods everywhere I did and did not go this summer. Initially, I planned to attend SLA in another waterlogged city, Seattle, but could not travel the twenty miles to the airport since the interstates were closed. Once the roads opened, I managed to book a flight to dry Los Angeles, and attended ALA in Anaheim.

ALA sure knows how to put on a show. The conference was full of celebrities, Jamie Lee Curtis, Ron Reagan, Dr. Terry Brazelton; book signings featured

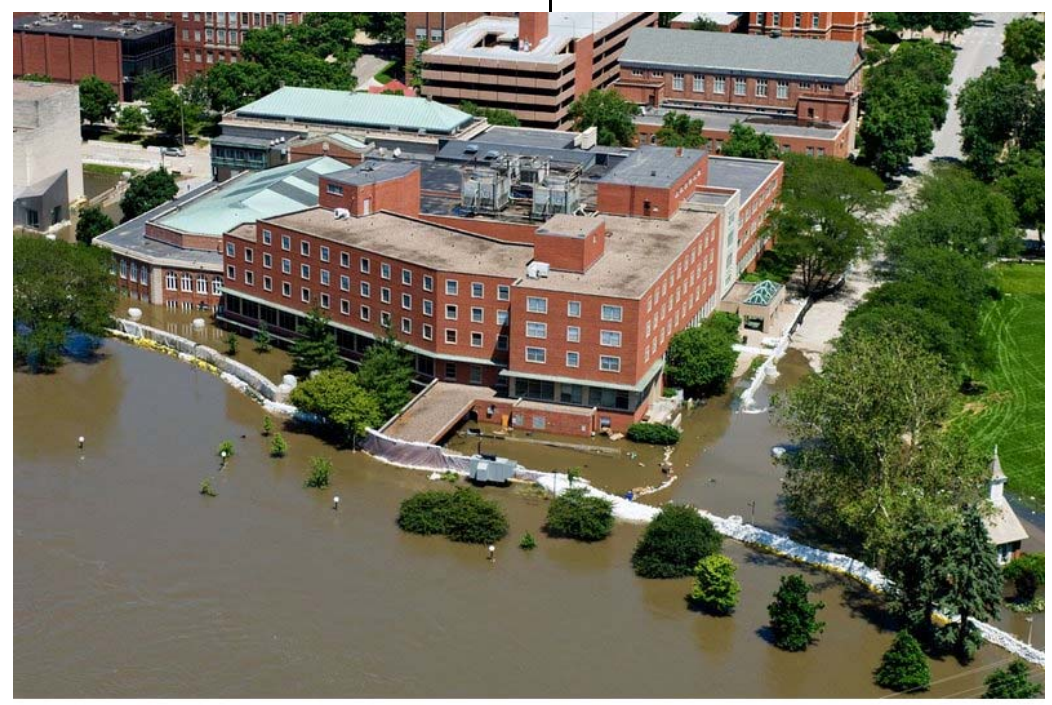

June 18 - Aerial photos of the Ul campus taken when the lowa River was about $\mathbf{3 1}$ feet. Flood stage for the lowa River at lowa City is 22 feet. The previous record was set in 1993 at 28.5 feet. the most recent Caldecott and Newbery winners. The vendors were out in force, marketing their wares, and talking to customers. And the sessions included food, food for thought, and references to food and the flood.

The first flood comment I encountered occurred when I attended a session titled, Making the Switch from Print to Online: Why, When and How? One of the presenters showed a photograph of the devastated public library in Parkersburg, Iowa, and said that if the collection had been online, the library would not have lost as much. I didn't realize that servers were waterproof. What about electricity; will it last forever?

Another flood reference came during the session of contributed research papers. The presenter, Dr. Lisl Zach from Drexel, examined how librarians behave in a crisis. Her research focused on whether librarians use their information skills to assist the community after a disaster strikes. Her preliminary findings show that librarians, themselves, were too overwhelmed to offer basic services. Instead, their volunteer efforts centered on helping the community with food, clothing, and shelter, rather than utilizing their superior skills to locate 
stories about authors who added positive reviews about their own books on amazon.com, and posted negative reviews about their competitors.

The presenters covered comic books, graphic novels, and gaming interests in the library. I learned that some music is composed only for the game, and is not released anywhere else.

In the session, Knowledge Wants to be Known: Open Access Issues for the Behavioral and Social Sciences, I discovered that open access has a friend in John Willinsky, professor of Education at Stanford. Dr. Willinsky single handedly promoted the concept, and established the Public Knowledge Project that produces software allowing other university libraries to host journals. Currently, thirty-four universities have an open access mandate. Benefits include immediate access to material, author control, and an increase in the number of times an author is cited. There were questions regarding what happens when faculty move from one institution to another. The session also included views from publishing (Alison Mudditt from Sage), and a college library (Ray English from Oberlin).

Judy Luther, the moderator of the program Making the Switch from Print to Online: Why, When and How, co-authored the ARL report, The E-only Tipping Point for Journals: What's Ahead in the Print-to-Electronic Transition Zone

(http://www.arl.org/bm doc/Electronic_Transition.pdf), a report everyone should read. One of the panelists, Elizabeth Rasmussen Martin from the University of Texas at Austin, described the difficulty of justifying the acquisition and maintenance of serials in dual formats; print and electronic. Tim Bucknell from the University of North Carolina at Greensboro indicated that online journals were less expensive, and patrons prefer them. On the publishers' side, Noella Owen from Springer emphasized the financial benefits since online serials eliminate binding costs, storage, and shipping, and facilitate concurrent usage. Springer is exploring on-demand printing for e-books. By describing her experiences, Kim Steinle presented a slightly different picture regarding Duke University Press' move to online material. For the most part, the Press spent more on offering online serials because of increases in and training of staff, and the need to work with new vendors. She found that there were new demands for keywords, definition of terms, and a higher level of customer service required.

To explore information literacy, or IL, from a slightly different angle, I attended the session, Is there a Right to Information Literacy? Academic Responsibility in the Information Age. The session focused on policy. Patricia Stanley, Deputy Assistant Secretary, U.S. Department of Education, Office of Vocational and Adult Education talked about the responsibility of K-12 educators to make sure that high school graduates are ready for work and college. She touched on early government legislation (Perkins), and programs (Pathways), and of course mentioned No Child Left Behind. She stressed the three A's, accessibility, accountability, and affordability, and said that IL is critical to students' successes.

Penny Beile presented the view from the frontlines as a librarian at the University of Central Florida. She talked about university policy, the course of action, and that UNESCO assigns the responsibility of IL to librarians. To illustrate how IL can become policy in a state university system, Lorie Roth, Assistant Vice-Chancellor, Academic Affairs, and Stephanie Sterling Brasley, Manager, Information Literacy Initiatives described in detail their experiences and success in instituting IL in the California State University system.

In addition to making attendees feel warm and fuzzy at breakfasts, lunches, and breaks, vendors talk about their products. A case in point was the breakfast sponsored by the American Psychological Association (APA). Over steel-cut porridge, Eggs Benedict, and scones, we learned that in 2009 APA will launch a new database of educational and psychological tests available from non-commercial sources. APA representatives also talked about copyright issues regarding their well-known APA Manual, and methods to promote "green" in their workplace such as instituting flex time for their employees.

I did allow myself one guilty pleasure; I attended a book talk that Jamie Lee Curtis gave to a group of 
children. I love Jamie Lee, and she did not disappoint. What a smart, funny, and sharp lady. During the question and answer session, the most pressing query came from a little boy who asked how Jamie Lee bumped into her co-star, Lindsay Lohan, in order to transform herself from mother to daughter in the film, Freaky Friday. Apparently, both actresses wore padding; lots of it.

Even though ALA took place in Anaheim, home of Disneyland, I did not pay a return visit to the park which I first visited when I was five years old, oh several decades ago. I didn't want to challenge my fond memories of Frontierland, and Tomorrowland. Besides, ALA provided an amusement park of its own, complete with food, intellectual stimulation, and a simulated roller coaster ride in the exhibit hall. I had all the excitement I could take plus endless sunshine.

Education Libraries (ISSN 0148-1061) is a publication of the Education Division, Special Libraries Association. It is published two times a year (Summer/Winter). Starting in 2009, current issues of Education Libraries will be available in full-text on the SLA Education Division's website at http://www.sla.org/division/ded/edlibs.html.

Education Libraries is indexed in Library Literature and the Current Index to Journals in Education. Permission to reprint articles must be obtained in writing from the Editors (or the original sources where noted). Opinions expressed in articles and book reviews are those of the authors and do not necessarily represent the views of the editors, Editorial Committee, or the members of the SLA Education Division.

\section{Officers of the Education Division, SLA for} 2008-2009: Chair: Lesley Farmer; Past Chairs: Sharon Weiner, Susan Couch; Secretary-Treasurer: Debbie Bogenschutz

\section{(C) 2008 - Special Libraries Association, Education Division}

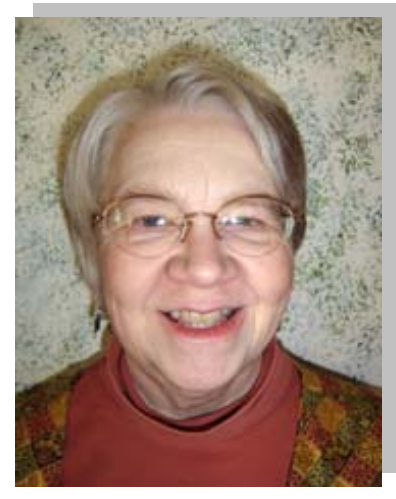

\section{A Letter from our Business \& Circulation Manager}

Thank you for your continued support of Education Libraries, the peer-reviewed journal of SLA's Education Division. Originally, Education Libraries was sent only to members of the Education Division.

When we began offering paid subscriptions, our circulation increased to libraries and scholars in over 40 countries on three continents. During this period of increasing costs and stagnant budgets, we have seen a drop in subscriptions. After much deliberation, we have decided to take steps to make Education Libraries available to a much wider global audience. Our members and subscribers will receive the Winter 2008 issue, Volume 31 (2) by email, as has been our recent practice. After that, we have decided that Education Libraries will be a free publication available to all through the Education Division's website:

\section{http://units.sla.org/division/ded/index.html.}

Our editors will continue to seek, review, and publish the same great content, but the result will now be available to researchers everywhere.

Volume 31 will be available at the website after a one-year embargo, as has been our policy. When Volume 32 is published, we will open the journal to all. Back issues for those volumes published electronically are now available at the website, and we will be working to bring more of the backlist online.

Again, thanks for your support through the years. We have appreciated having you as subscribers, and we hope you'll enjoy our new availability.

\section{Debbie Bogenschutz, MSLS, MA}

Coordinator of Information Services

Johnnie Mae Berry Library

debbie.bogenschutz@cincinnatistate.edu

513-569-1611 tel 513-559-0040 fax 